\title{
Morphological and Receptorial Changes in the Epididymal Adipose Tissue of Rats Subjected to a Stressful Stimulus
}

\author{
Enrico Campioli ${ }^{1,2}$, Gianluca Carnevale ${ }^{1,2}$, Rossella Avallone ${ }^{1,2}$, Deanna Guerra ${ }^{1}$ and Mario Baraldi ${ }^{1,2}$
}

Obesity is nowadays related to other pathological conditions such as inflammation, insulin resistance, and diabetes, but little is known about the relationship between psychological stress and adipocytes. We decided to study the expression of the translocator protein (TSPO) 18-kDa, peroxisome proliferator-activated receptor- $\gamma$ (PPAR- $\gamma$ ), mitochondrial uncoupling protein-1 (UCP-1), and adipocyte morphology in the adipose tissue of rats subjected to stress conditions. In our model of stress, rats fasted for $24 \mathrm{~h}$ were placed in a restraint cage and then immersed vertically to the level of the xiphoid process in a water bath at $23^{\circ} \mathrm{C}$ for $7 \mathrm{~h}$. After that period, we removed the epididymal adipose tissues for the subsequent analysis. The optical and electron microscopy revealed that adipocytes of control rats formed a continuous epithelial-like cell layer; on the contrary in the adipocytes of stressed rats some cells have merged together and the number of vessels formed seems to increase. Stressed adipocytes presented unilocular cells with numerous mitochondria with a morphology ranging between that of brown adipose tissue (BAT) and white adipose tissue (WAT). Interestingly, when we investigated the subcellular distribution of UCP-1 by immunogold electron microscopy, the adipose tissue of stressed rats was positive for UCP-1. From the immunoblot analysis with anti-PPAR- $\gamma$ antibody, we observed an increased expression of PPAR- $\gamma$ in the adipocytes of stressed group compared with control group $(P<0.05)$. Stress induced the expression of TSPO 18-kDa receptor $\left(B_{\max }=106.45 \pm 5.87 \mathrm{fmol} / \mathrm{mg}\right.$ proteins), which is undetectable by saturation-binding assay with [ $\left.{ }^{3} \mathrm{H}\right] \mathrm{PK} 11195$ in the control group.

Obesity (2011) 19, 703-708. doi:10.1038/oby.2010.244

\section{INTRODUCTION}

The translocator protein $18-\mathrm{kDa}$ (TSPO $18-\mathrm{kDa})$, previously known as peripheral-type benzodiazepine receptor (1), is widely expressed throughout the human and animal body and it is present in high levels in steroidogenic tissues (2). The TSPO $18-\mathrm{kDa}$ is mainly localized in the outer mitochondrial membrane, where it is responsible for various functions whether pathological or physiological. Some of these functions include: cholesterol transport into mitochondria (1), steroid biosynthesis $(1,3)$, activation of cell survival mechanisms (1), mitochondrial oxidative phosphorylation (4), and cell proliferation (2). Finally, its overexpression is correlated with the progression of some types of cancer (breast, colon, liver, and prostate) and it is involved in stress-related psychiatric disorders $(1,2)$.

The presence and functions of TSPO $18-\mathrm{kDa}$ in the adipose tissue is not well documented, as a matter of fact it was previously detected by radioligand-binding assay only in the interscapular brown adipose tissue (BAT) (5). A study of 2005 demonstrated for the first time that TSPO $18-\mathrm{kDa}$ complementary mRNA is upregulated during adipogenesis in a 3T3-L1 cell line model (6). On the contrary, the additional role for TSPO $18-\mathrm{kDa}$ in stress-related pathologies has been widely demonstrated over the years especially in adrenal gland, kidney, and platelets. The receptor increases after $24 \mathrm{~h}$ of acute stress (7-9), but it decreases after 3 weeks of repeated stress $(7,10,11)$. More recently, it has been demonstrated that after an acute stressful stimulus hippocampal and adrenal gland TSPO $18-\mathrm{kDa}$ density decreased after $1 \mathrm{~h}$ of stress (12), but the density dramatically increased after $24 \mathrm{~h}$.

In a rat model of carrageenin-induced paw edema (CIPE), high doses of diazepam $(10.0-20.0 \mathrm{mg} / \mathrm{kg})$ were shown to reduce the volume of acute inflammatory paw edema, possibly by activating mitochondrial TSPO in adrenal cells. After activation, the serum levels of corticosterone are increased leading to a reduced CIPE (13). When PK11195 (TSPO 18-kDa antagonist) is administered the effect of diazepam on CIPE is suppressed as well as after adrenalectomy (13). Long-term diazepam treatment does not change either the corticosterone 
serum levels or the CIPE (14). Diazepam appears to be effective in the acute treatment of CIPE, because individuals exhibit resistance to the drug when taken for long periods.

Rats and mice subjected to cold have an increased expression of mitochondrial uncoupling protein-1 (UCP-1) (15-18), an increased number of brown adipocytes $(16,18)$, and an increased density of mitochondrial cristae $(18,19)$. It has been demonstrated that the expression of UCP-1 protein increased following the administration of peroxisome proliferatoractivated receptor- $\gamma$ (PPAR- $\gamma$ ) agonist (20). On the contrary, in mice with a dominant-negative PPAR- $\gamma$ mutation (P465L) there is a reduction in brown adipocytes recruitment from white adipose tissue (WAT) depots (transdifferentiation) and a reduced expression of UCP-1 (21).

Numerous studies are considering the close relationship between stress and inflammation (22-24) and more recently the involvement of inflammatory processes in diseases such as obesity, diabetes, and insulin resistance $(25,26)$.

For these reasons, we decided to study TSPO $18-\mathrm{kDa}, \mathrm{PPAR}-\gamma$, UCP-1 as well as the adipocytes morphology in the epididymal adipose tissue of rats subjected to stress conditions.

\section{METHODS AND PROCEDURES \\ Stress-induced model}

A total of 20 adult male Sprague-Dawley rats (Charles River Laboratories, Milano, Italy) weighing 200-250 g were randomly divided in two groups: control and stressed. They were housed in a controlled environment, maintained under a 12:12-h light/dark cycle, and had free access to water and food. The animals were deprived of food but were allowed free access to water for $24 \mathrm{~h}$ before the experiment.

Rats were placed in a restraint cage and then immersed vertically to the level of the xiphoid process in a water bath at $23^{\circ} \mathrm{C}$, according to the model proposed by Takagi and Okabe (27) with some variation. After $7 \mathrm{~h}$, the animals were anesthetized with $\mathrm{CO}_{2}(\mathrm{~g})$ and killed by decapitation. Rapidly epididymal adipose tissues were removed and stored at $-80^{\circ} \mathrm{C}$.

The assessment of the gastric mucosa damage following the ulcerogenic stimulus was accomplished by giving a score from 0 (normal mucosa) to 5 (perforated ulcer) as previously described (27).

All procedures were performed in accordance with the guidelines of the National (D.L. no. 116/1992) and European legislation (EEC no. 86/609) and of the National Institute of Health on the use and care of laboratory animals.

\section{Light and electron microscopy}

We used three different methods to fix the tissue to better evaluate the adipocytes and we named them, respectively, methods 1,2 , and 3 .

Method 1 is the standard electron microscopy fixation method. Tissues were fixed in $2.5 \%$ glutaraldehyde (Sigma-Aldrich Italy, Milano, Italy) in $0.1 \mathrm{~mol} / \mathrm{l}$ phosphate-buffered saline (PBS) ( $\mathrm{pH} 7.4$; Sigma-Aldrich Italy) at $4{ }^{\circ} \mathrm{C}$ for $24 \mathrm{~h}$. The tissues were then rinsed in PBS and postfixed for $2 \mathrm{~h}$ in $1 \%$ osmium tetroxide (Sigma-Aldrich Italy) in PBS. Tissues were dehydrated in a series of ethanol solutions (30,50, 70, 90, and $100 \%$; all purchased from Sigma-Aldrich Italy) and propylene oxide (SigmaAldrich Italy), and then embedded in TAAB low-viscosity resin (TAAB Laboratories Equipment, Aldermaston, UK), which was polymerized at $60^{\circ} \mathrm{C}$ for $24 \mathrm{~h}$.

In method 2, tissues were fixed in 3\% glutaraldehyde (Sigma-Aldrich Italy), $0.1 \%$ malachite green (Sigma-Aldrich Italy) in $0.1 \mathrm{~mol} / \mathrm{l}$ cacodylate buffer ( $\mathrm{pH} 6.8$; Sigma-Aldrich Italy) at $4^{\circ} \mathrm{C}$ for $24 \mathrm{~h}$ (28). The tissues were then rinsed in cacodylate buffer (Sigma-Aldrich Italy) and postfixed for $2 \mathrm{~h}$ in $2 \%$ osmium tetroxide (Sigma-Aldrich Italy) in cacodylate buffer.
Tissues were then embedded after dehydrating in a series of ethanol solutions and propylene oxide.

In method 3 , tissues were fixed in $4 \%$ osmium tetroxide (SigmaAldrich Italy) in $0.1 \mathrm{~mol} / \mathrm{l}$ cacodylate buffer ( $\mathrm{pH} 6.8$; Sigma-Aldrich Italy) at $4{ }^{\circ} \mathrm{C}$ for $24 \mathrm{~h}$. Tissues were then rinsed in $0.1 \mathrm{~mol} / \mathrm{l}$ cacodylate buffer (Sigma-Aldrich Italy) and postfixed for $2 \mathrm{~h}$ in $2.5 \%$ glutaraldehyde (Sigma-Aldrich Italy) and $0.25 \%$ tannic acid (Sigma-Aldrich Italy) in $0.1 \mathrm{~mol} / \mathrm{l}$ cacodylate buffer (Sigma-Aldrich Italy). As osmium tetroxide determines lipid extraction during dehydration phase, it is necessary to double fix with glutaraldehyde and tannic acid, which stabilize the tissue (29). Finally, tissues were then embedded after dehydrating in a series of ethanol solutions and propylene oxide.

For the optical microscopy, thin sections $(0.83 \mu \mathrm{m})$ were stained with toluidene blue (Sigma-Aldrich Italy) and sodium tetraborate (Sigma-Aldrich Italy), and then observed with a Zeiss Axiophot microscope (Zeis, Milan, Italy).

For the electron microscopy, ultrathin sections $(80 \mathrm{~nm})$ were stained with uranyl acetate (Sigma-Aldrich Italy) and lead citrate (Sigma-Aldrich Italy) by Reynold's, and then observed with a Joel 1200 EXII microscope (Joel, Milan, Italy).

\section{TSPO 18-kDa receptor saturation-binding assay}

In saturation-binding assays, increasing concentrations of $\left[{ }^{3} \mathrm{H}\right] \mathrm{PK} 11195$ $(20 \mu \mathrm{l}, 0.73-23.2 \mathrm{nmol} / \mathrm{l}$; specific activity $3.09 \mathrm{TBq} / \mathrm{mmol}$; NEN Life Science Products; PerkinElmer Italy, Milano, Italy) were incubated with both control and stressed rat adipose tissue membranes $(160 \mu \mathrm{l}, 2-10 \mu \mathrm{g}$ of protein $/ \mathrm{ml}$ ) prepared as previously described by Anholt for adrenal glands (30). Protein concentration was determined by the method of Bradford (31) with bovine serum albumin used as a standard. The final volume $(200 \mu \mathrm{l})$ was obtained by adding water and nonspecific binding was measured in the presence of unlabeled PK 11195 (Sigma-Aldrich Italy) $1 \mu \mathrm{mol} / \mathrm{l}$.

The mixture was incubated at $0-4^{\circ} \mathrm{C}$ for $1 \mathrm{~h}$. The reaction was terminated by vacuum filtration through glass-fiber filters (Whatman GF/C; Whatman International, Maidstone, UK) presoaked in $0.5 \%$ polyethyleneimine (Sigma-Aldrich Italy) followed by three washings with $3 \mathrm{ml}$ of ice-cold Tris-HCl buffer (Sigma-Aldrich Italy). The filters were transferred to vials with liquid scintillation cocktail $(3 \mathrm{ml})$ and radioactivity was measured in an LS 1701 RackBeta liquid scintillation counter (Beckman Coulter, Milano, Italy). Saturation Scatchard plots of all the samples were analyzed by GraphPad program (GraphPad Software, La Jolla, CA) to obtain maximal number of receptors $\left(B_{\text {max }}\right)$.

\section{Immunohistochemistry}

The indirect immunogold method has been used; serial ultrathin sections were hydrated in PBS for $10 \mathrm{~min}$ and were etched with $10 \%$ hydrogen peroxide (Sigma-Aldrich Italy) for $10 \mathrm{~min}$ at room temperature and rinsed in PBS. Then, some ultrathin sections were preincubated for $30 \mathrm{~min}$ at room temperature in $1 \%$ bovine serum albumin, $1 \%$ Tween-20, and $0.01 \% \mathrm{NaN}_{3}$ (Sigma-Aldrich Italy). Some sections were preincubated in $1 \%$ egg albumin, $1 \%$ Tween- 20 , and $0.01 \% \mathrm{NaN}_{3}$ (Sigma-Aldrich Italy) before incubation overnight at $4{ }^{\circ} \mathrm{C}$ with the primary UCP-1 antibody (1:10 dilution; Abcam, Cambridge, UK) diluted in the same medium.

Each incubation was followed by six washes in PBS and Tris buffer of 3 min each, then for $15 \mathrm{~min}$ in $0.2 \%$ bovine serum albumin or egg albumin in Tris $\mathrm{pH}$ 8.4. The sections were immunostained with colloidal gold-conjugated secondary antibodies (goat anti-rabbit IgG, 1:20 dilution; Società Italiana Chimici, Divisione Scientifica, Rome, Italy) diluted in Tris buffer, $\mathrm{pH} 8.4$ and 1\% bovine serum albumin or egg albumin for $1 \mathrm{~h}$ at room temperature. For negative controls, sections were incubated without primary antibody, without secondary antibody, without primary and secondary antibodies.

Finally, after washes with Tris buffer and distilled water, sections were stained with uranyl acetate and lead citrate (Sigma-Aldrich Italy) and observed with electron microscope. 


\section{Immunoblotting}

Rat's tissues were homogenized in an extraction buffer containing sodium chloride $140 \mathrm{mmol} / \mathrm{l}$, potassium chloride $2 \mathrm{mmol} / \mathrm{l}$, potassium phosphate monobasic $1.5 \mathrm{mmol} / \mathrm{l}$, sodium phosphate dibasic $15 \mathrm{mmol} / \mathrm{l}$, sodium deoxycholate $0.5 \%$, sodium dodecyl sulfate $0.1 \%$, and Nonidet P40 1\% (all purchased from Sigma-Aldrich Italy). Fresh mixture Protease Inhibitor Cocktail (Sigma-Aldrich Italy) was added to homogenates. Protein extracts were obtained by centrifugation of the homogenate at $4^{\circ} \mathrm{C}$, and the protein concentration was measured with Bradford assay (31).

Proteins were separated by sodium dodecyl sulfate-polyacrylamide gel electrophoresis, then transferred to nitrocellulose membrane (Invitrogen, Milano, Italy), and blocked overnight at $4{ }^{\circ} \mathrm{C}$ in blocking buffer $(20 \mathrm{nmol} / \mathrm{l}$ Trizma Base, $100 \mathrm{mmol} / \mathrm{lNaCl}, 1 \%$ Tween-20, and $10 \%$ skim milk; SigmaAldrich Italy). Membranes were first incubated for $3 \mathrm{~h}$ at room temperature with a rabbit IgG anti-PPAR- $\gamma$ polyclonal antibody (1:500 dilution; Cayman Chemical, Ann Arbor, MI). Finally, membranes were incubated for $1 \mathrm{~h}$ at room temperature with a goat anti-rabbit IgG $\operatorname{HRP}(1: 4,000$ dilution; Cayman Chemical).

After conjugation with the secondary antibody, the complex was visualized using an Amersham chemiluminescence kit (GE Healthcare Europe-Filiale Italiana, Milano, Italy). To verify the uniformity of protein loading, each sample was also incubated with anti- $\beta$-tubulin $(1: 1,000$ dilution; Upstate, Millipore, Billerica, MA).

Band intensity was quantified by densitometry measurements of autoradiographs analyzed by a Bio-Rad GS-690 Scanner (Bio-Rad, Milano, Italy). Optical densities of samples were normalized to that of $\beta$-tubulin.

\section{Statistical analysis}

Data, expressed as mean \pm s.e.m. and $N$, were analyzed with an unpaired $t$-test between control group and stressed group by using the GraphPad Prism program (GraphPad Software). $P<0.05\left(^{*}\right)$ and $P<0.001\left(^{* * *}\right)$ were taken as the level of significance.

\section{RESULTS}

\section{Effect of stress on rat gastric mucosa}

We observed the formation of gastric ulcers $(10.30 \pm 2.00$; mean \pm s.e.m., $n=10,{ }^{* *} P<0.001$ with unpaired $t$-test compared to control) after $7 \mathrm{~h}$ from exposure to stress (Figure 1). The evaluation of ulcers after the seventh hour, according to the ulcerogenic score, gave results as $0.00 \pm 0.00$ for control group and $3.80 \pm 0.30$ (more than three large ulcers with diameter of $1 \mathrm{~mm}^{2}$ ) for the stressed group. As reported previously by Takagi and Okabe (27), the presence of ulcers is a positive control to determine the state of stress in the animal.

\section{Light and electron microscopy}

The epididymal adipose tissue had a different consistency in control rats compared with stressed rats. Macroscopically the adipose tissue of stressed rats was more brittle and dark than the control group adipose tissue.

Optical microscopy showed that the control adipose tissue is composed of large polyhedral oval cells $(50-83 \mu \mathrm{m})$ that are closely joined together. The nucleus and cellular organelles are located at the cell periphery, the cytoplasm has a single drop of fatty acids (Figure 2a,c,e). The connective tissue is thin with rare blood capillaries and little lipid globules. Cells form a continuous epithelial-like cell layer, which is evident in micrographs obtained by specific lipid-staining samples (methods 2 and 3 , corresponding to Figure $2 \mathbf{c}-\mathbf{f}$ ). Lipid membranes of


Figure 1 Animal model of stress: rats, fasted for $24 \mathrm{~h}$, were placed in a restraint cage and then immersed vertically to the level of the xiphoid process in a water bath at $23^{\circ} \mathrm{C}$ for $7 \mathrm{~h}$. (a) Control rat mucosa and (b) stressed rat mucosa; blue arrows point out the gastric ulcers $\left(10.30 \pm 2.00\right.$; mean \pm s.e.m., $n=10,{ }^{\star \star *} P<0.001$ with unpaired $t$-test compared to control).
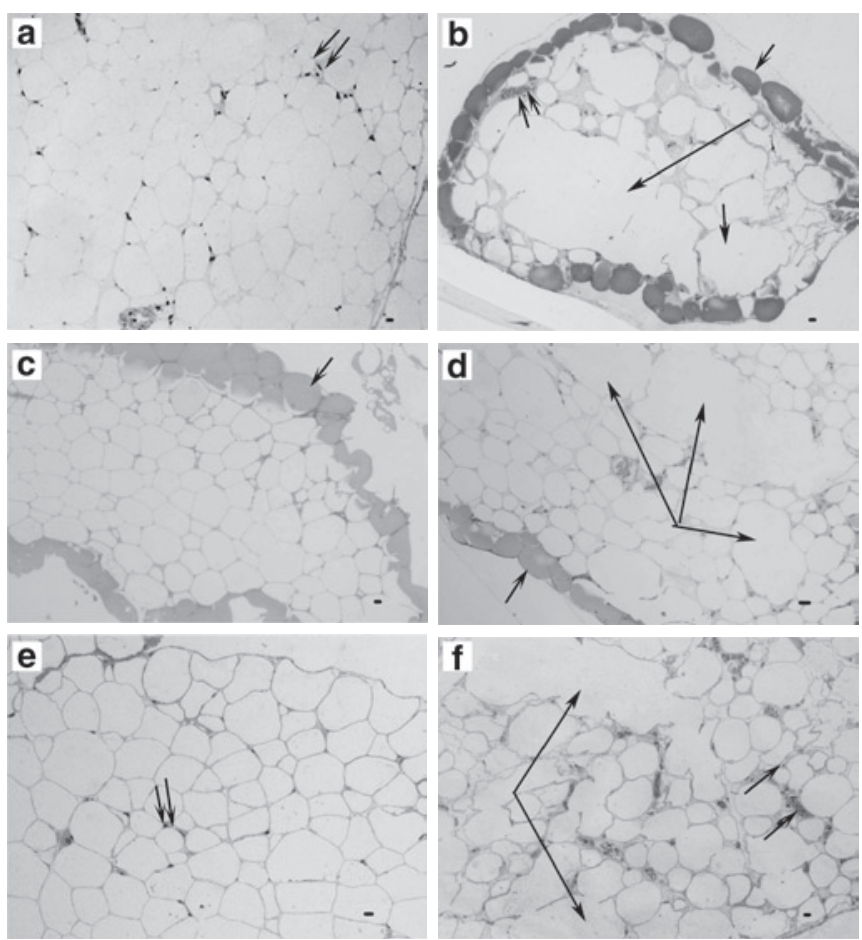

Figure 2 Optical micrographs of control and stressed rats: (a) control rats prepared with method 1 , (b) stressed rats prepared with method 1 , (c) control rats prepared with method 2, (d) stressed rats prepared with method 2, (e) control rats prepared with method 3, and (f) stressed rats prepared with method 3 . Fixatives and dyes used have different rates of penetration into the tissue, hence the adipocyte surface appears darker and well preserved (small arrow). Both control and stressed rats present white adipocytes showing large lipid vacuoles surrounded by a thin cytoplasm containing few flattened nuclei (double small arrow). In stressed rats, note the presence of large lipid globules (arrow) and numerous blood vessels (double arrow). Objective $\times 40$, bar $=1 \mu \mathrm{m}$.

cells fixed with method 1 are less regular, and lipids seem to be slightly coerced (Figure 2a,b). The stressed rat adipose tissue showed a clear cell polymorphism, some cells had normal shape and size $(40-83 \mu \mathrm{m})$, but some of them seemed to be merged together in clusters of two or more cells. As a matter of fact, initial elements were no longer recognizable and these new adipocytes were bigger than the others $(100-416 \mu \mathrm{m})$, and they had an intermediate morphology between unilocular and 

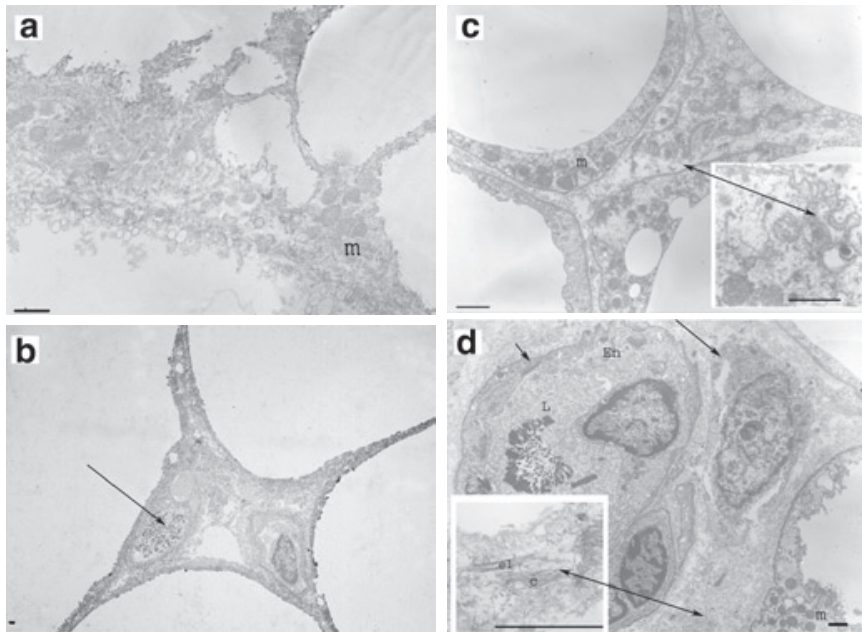

Figure 3 Transmission electron microscopy of epididymis: (a,b) control and (c,d) stressed rat. (a) Multilocular cells have granular cytoplasm with some vesicles (arrow) and typical (M) and atypical mitochondria.

(b) Young adipocytes have a cluster of glycogen particles (arrow).

(c) Some adipocytes are in intercellular contact, two types of gap junctions are showing flat and pus-button (arrow inset) and in the cytoplasm there are some small lipid droplets. (d) The blood vessel have endothelial cell (En) that form tight junction (arrow) and the lumen (L) is wide. In pericytic position, note a cell with a high nucleus/cytoplasm ratio, endoplasmic reticulum is weakly dilated (arrow), at the top and bottom the cell shows two nuclei. In the extracellular matrix, we can recognize elastic fibers (el) with numerous microfibers and collagen (c). Original magnification: (a) $\times 7,500$; (b) $\times 4,200$; (c) $\times 9,200$, (inset) $\times 15,000$; (d) $\times 5,100$, (inset) $\times 29,000$; bar $=1 \mu \mathrm{m}$.

Table 1 TSPO 18-kDa adipose tissue expression

\begin{tabular}{lcc}
\hline Group & fmol/mg proteins & $K_{\mathrm{d}}$ \\
\hline Control & n.d. & n.d. \\
Stressed & $106.45 \pm 5.87^{\text {** }}$ & $1.9 \pm 0.35^{\text {** }}$ \\
\hline
\end{tabular}

Values are means \pm s.e.m. $(n=10)$.

n.d., not detectable; TSPO, translocator protein

${ }^{\star \star \star} P<0.001$ with unpaired $t$-test.

multilocular cells. The interstitial connective tissue is increased, as the number of blood vessels (Figure $2 \mathbf{b}, \mathbf{d}, \mathbf{f}$ ).

Electron microscopy revealed signs of early autolytic changes, such as slight disarrangement of cell membranes, due to freezing of the samples by liquid nitrogen without optimal cutting temperature compound and stored at $-80^{\circ} \mathrm{C}$ before chemical fixation. Nevertheless, mitochondrial ultrastructure was rather well preserved especially the one obtained by method 2; therefore, all the electron micrographs presented in this study were fixed with $3 \%$ glutaraldehyde $+0.1 \%$ malachite green and postfixed with $2 \%$ osmium tetroxide.

Analysis of samples from control rats pointed out the presence of at least three types of cells: cells with numerous typical (Figure 3a) and atypical WAT-like mitochondria (data not shown), weakly differentiated cells with multivacuolar lipid and granular cytoplasm (Figure 3a) and young adipocytes with clusters of glycogen particles (Figure 3b).

Instead, in the stressed adipose tissue, we observed a different tissue layout: increasing concentration of blood capillaries
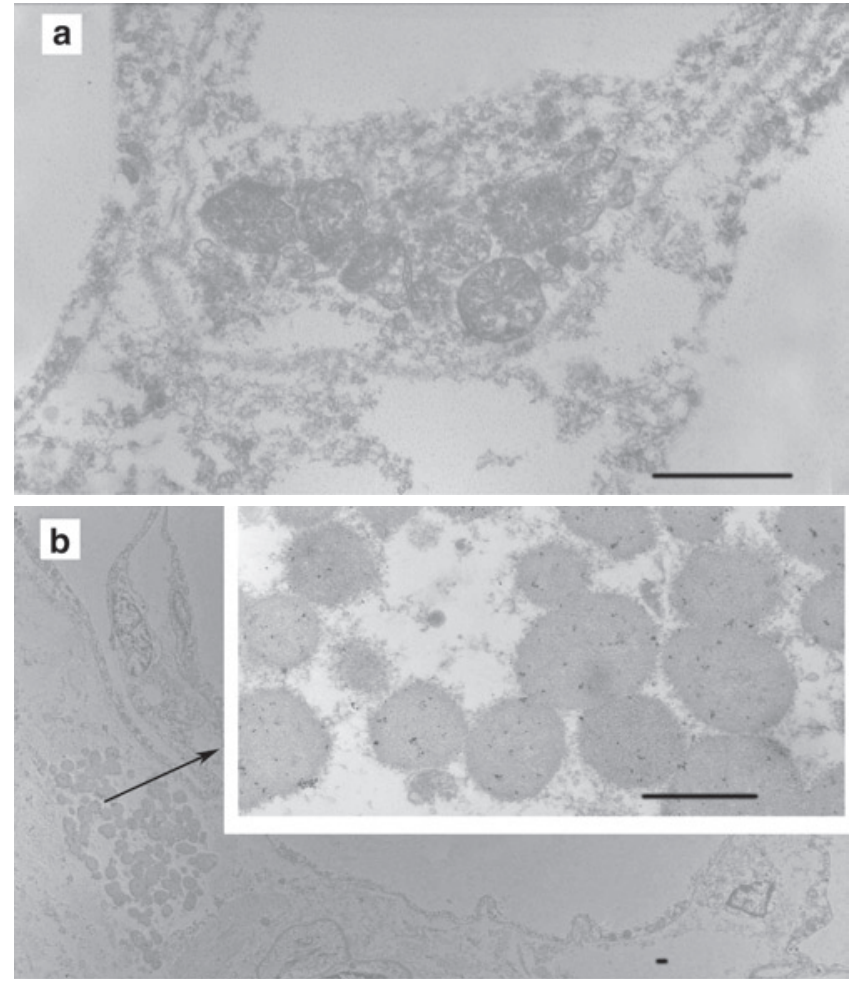

Figure 4 Immunogold electron microscopy with anti-rat uncoupling protein-1 antibody. (a) The immunoreaction is negative in rat control adipose tissue. (b) Mitochondria show a morphology between brown adipose tissue (BAT) and white adipose tissue (WAT) and they are positive for immunoreactions to uncoupling protein (inset). Original magnification: $(a) \times 16,000$; (b) $\times 19,500$; bar $=1 \mu \mathrm{m}$.

and young adipocytes with cytoplasm rich in glycogen particles. Glycogen was abundant and displayed in large clusters. The shape of these cells was either oval, polygonal, elongated, or sometimes showed bundles of filaments in the cytoplasm, but endoplasmic reticulum was always scarce (data not shown). Unilocular cells had numerous small lipid droplets in the peripheral cytoplasm, some of them containing plasma membrane with villous morphology and intercellular contacts that looked like flat gap junctions (Figure 3c) or push-button gap junctions (Figure 3c, inset). Chylomicron-like structures were seen as transparent vesicles, isolated or clustered and lamellar whorls were present in the intercellular space (Figure 3c, inset).

Capillary blood consists of endothelial cells whose apposing membranes form tight junctions, which limit the passage of water and solutes, in a pericytic position there was a hyperplastic cell, which had a high nucleus/cytoplasm ratio, a welldeveloped nucleolus, reticular endoplasmic mitochondria, and external lamina (Figure 3d).

The extracellular matrix had increased well-structured collagen fibers, and small elastic fibers with numerous microfibers (Figure 3d, inset).

\section{TSPO 18-kDa adipose tissue expression}

Saturation-binding experiments of control rat adipose tissue gave no results because the saturation point was not reached, so 


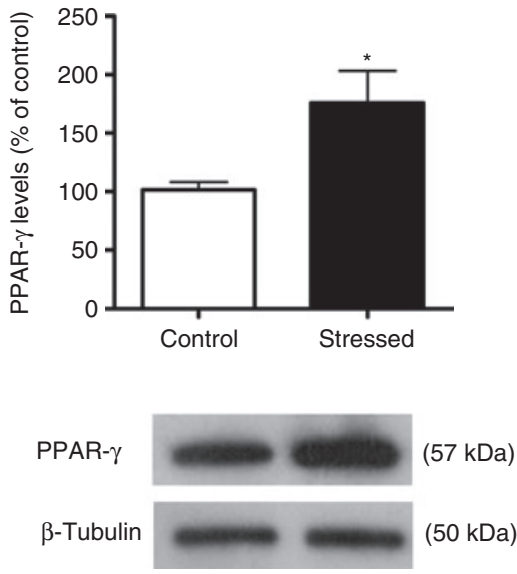

Figure 5 Immunoblot analysis for peroxisome proliferator-activated receptor- $\gamma$ (PPAR- $\gamma$ ). Stress increases the adipose tissue expression of PPAR- $\gamma$ as determined by western blot. All data expressed as mean \pm s.e.m. $(n=10)$ per treatment were analyzed using unpaired $t$-test $\left({ }^{*} P<0.05\right)$.

the emitted radioactivity was due to aspecific binding. Instead, in stressed rat adipose tissue, saturation point was obtained and the Scatchard analysis indicated a maximal number of binding sites $\left(B_{\max }\right)$ of $106.45 \pm 5.87 \mathrm{fmol} / \mathrm{mg}$ proteins (mean \pm s.e.m., $n=10)$ and an affinity of $1.9 \pm 0.35 \mathrm{nmol} / \mathrm{l}$ (Table 1 ).

\section{Immunogold electron microscopy of UCP-1}

Immunogold electron microscopy of control rat adipose tissue showed no reaction to anti-UCP-1 antibody (Figure 4a), as well as negative controls; as a matter of fact in these sections colloidal gold particles are not visible (data not shown).

Adipose tissue of stressed rats presented unilocular cells with numerous mitochondria, showing a morphology between BAT and WAT. These were positive for anti-inner mitochondrial membrane UCP-1 that is considered a proton carrier unique to BAT (Figure $4 b$ ).

\section{PPAR- $\gamma$ adipose tissue expression}

Western blot analysis of adipose tissue (Figure 5) analyzed by densitometry showed an increased expression of PPAR- $\gamma$ in the stressed group $(n=10)$ compared with control group $(n=$ 10) with $P<0.05$ (unpaired $t$-test).

\section{DISCUSSION}

The problem of obesity, as remarked by the World Health Organization, has exploded in the Western world as a result of changes in social life (32). This natural tendency to fattening, associated with hectic and stressful everyday life, can be an aggravating factor for diseases such as hypertension and obesity.

The histology of the two types of adipose tissue revealed that stressed rats have some larger adipocytes, which seem to have fused together, probably due to the ability of PPAR- $\gamma$ to increase the cellular lipid intake (33-35). Gealekman et al. demonstrated that rosiglitazone (a PPAR- $\gamma$-specific agonist) exerts a proangiogenic effect through the production of vascular endothelial growth factor A and angiopoietin-related protein 4 (36). These proangiogenic factors together, in response to PPAR- $\gamma$ activation, could lead to an expansion of the capillary network in the adipose tissue, which is required for its growth. In our model, stressed rats had a different type of adipose tissue compared to control rats with an increased number of blood vessels.

In this study, we observed that stressed rats increased the expression of UCP- 1 in the mitochondria and PPAR- $\gamma$. It must be stressed, however, that at variance with previous works, we used a rat model of stress with an objective and measurable stress pathology (gastric ulceration), which is different from the only change in body temperature.

It is well known that the TSPO $18-\mathrm{kDa}$ is localized to mitochondria, and BAT is richer in mitochondria than WAT $(16,18)$. The results reported here show that WAT of a stressed rat begins to transdifferentiate into $\mathrm{BAT}$, and such tissue change is accompanied by an increase of TSPO $18-\mathrm{kDa}$ protein. The saturation binding pointed out that TSPO is not detectable in control rats and weakly expressed in stressed rat (106.45 \pm $5.87 \mathrm{fmol} / \mathrm{mg}$ proteins). The finding is not surprising, because TSPO was previously detected by radioligand-binding assay only in the interscapular BAT (5). The relationship between PPAR- $\gamma$ and TSPO $18-\mathrm{kDa}$ is still unknown; there are only few studies suggesting a possible interaction between the TSPO $18-\mathrm{kDa}$ and PPAR family. Gazouli et al. demonstrated that peroxisome proliferators decrease the levels of testis TSPO $18-\mathrm{kDa}$ messenger RNA and circulating testosterone levels in mice through the action of PPAR- $\alpha$ (37).

In conclusion, according to our results, we have demonstrated that after a stressful stimulus we could observe a general modification of the adipose tissue morphology and an increased expression of PPAR- $\gamma$ and TSPO $18-\mathrm{kDa}$.

Further studies are needed to investigate the role of TSPO in obesity-related diseases, especially its relationship with the PPAR family. The present results seem to be of pivotal importance to highlight the biochemical mechanism, which regulates the stress-related changes in body weight balance.

\section{ACKNOWLEDGMENTS}

We thank Jessika Roggiani for her valuable contribution in the histological assay, Vassilios Papadopoulos and Amani Batarseh for their critical review of the manuscript. We had no funding support for this research.

\section{DISCLOSURE}

The authors declared no conflict of interest.

\section{(C) 2010 The Obesity Society}

\section{REFERENCES}

1. Papadopoulos V, Baraldi M, Guilarte TR et al. Translocator protein (18kDa): new nomenclature for the peripheral-type benzodiazepine receptor based on its structure and molecular function. Trends Pharmacol Sci 2006;27: 402-409.

2. Gavish M, Bachman I, Shoukrun R et al. Enigma of the peripheral benzodiazepine receptor. Pharmacol Rev 1999;51:629-650.

3. Lacapère JJ, Papadopoulos V. Peripheral-type benzodiazepine receptor: structure and function of a cholesterol-binding protein in steroid and bile acid biosynthesis. Steroids 2003;68:569-585.

4. Taupin V, Herbelin A, Descamps-Latscha B, Zavala F. Endogenous anxiogenic peptide, ODN-diazepam-binding inhibitor, and benzodiazepines enhance the production of interleukin-1 and tumor necrosis factor by human monocytes. Lymphokine Cytokine Res 1991;10:7-13. 
5. Gonzalez Solveyra C, Romeo HE, Rosenstein RE, Estevez AG, Cardinali DP. Benzodiazepine binding sites in rat interscapular brown adipose tissue: effect of cold environment, denervation and endocrine ablations. Life Sci 1988;42:393-402.

6. Wade FM, Wakade C, Mahesh VB, Brann DW. Differential expression of the peripheral benzodiazepine receptor and gremlin during adipogenesis. Obes Res 2005:13:818-822.

7. Drugan RC, Basile AS, Crawley JN, Paul SM, Skolnick P. Inescapable shock reduces [3H]Ro 5-4864 binding to "peripheral-type" benzodiazepine receptors in the rat. Pharmacol Biochem Behav 1986;24:1673-1677.

8. Basile AS, Weissman BA, Skolnick P. Maximal electroshock increases the density of [3H]Ro 5-4864 binding to mouse cerebral cortex. Brain Res Bull 1987:19:1-7.

9. Okun F, Weizman R, Katz $Y$ et al. Increase in central and peripheral benzodiazepine receptors following surgery. Brain Res 1988;458:31-36.

10. Weizman A, Bidder M, Fares F, Gavish M. Food deprivation modulates $\gamma$-aminobutyric acid receptors and peripheral benzodiazepine binding sites in rats. Brain Res 1990;535:96-100.

11. Dar DE, Weizman A, Karp L et al. Platelet peripheral benzodiazepine receptors in repeated stress. Life Sci 1991;48:341-346.

12. Avital A, Richter-Levin G, Leschiner $S$ et al. Acute and repeated swim stress effects on peripheral benzodiazepine receptors in the rat hippocampus, adrenal, and kidney. Neuropsychopharmacology 2001;25:669-678.

13. Lazzarini R, Malucelli BE, Palermo-Neto J. Reduction of acute inflammation in rats by diazepam: role of peripheral benzodiazepine receptors and corticosterone. Immunopharmacol Immunotoxicol 2001;23:253-265.

14. Lazzarini R, Malucelli BE, Muscará MN, de Nucci G, Palermo-Neto J. Reduction of inflammation in rats by diazepam: tolerance development. Life Sci 2003;72:2361-2368.

15. Ricquier D, Mory G, Bouillaud F, Thibault J, Weissenbach J. Rapid increase of mitochondrial uncoupling protein and its mRNA in stimulated brown adipose tissue. Use of a cDNA probe. FEBS Lett 1984;178: 240-244.

16. Young P, Arch JR, Ashwell M. Brown adipose tissue in the parametrial fat pad of the mouse. FEBS Lett 1984;167:10-14.

17. Jacobsson A, Stadler U, Glotzer MA, Kozak LP. Mitochondrial uncoupling protein from mouse brown fat. Molecular cloning, genetic mapping, and mRNA expression. J Biol Chem 1985;260:16250-16254.

18. Cousin B, Cinti S, Morroni M et al. Occurrence of brown adipocytes in rat white adipose tissue: molecular and morphological characterization. $J$ Cell Sci 1992;103 (Pt 4):931-942.

19. Loncar D, Afzelius BA, Cannon B. Epididymal white adipose tissue after cold stress in rats. II. Mitochondrial changes. J Ultrastruct Mol Struct Res 1988;101:199-209.

20. Sears IB, MacGinnitie MA, Kovacs LG, Graves RA. Differentiationdependent expression of the brown adipocyte uncoupling protein gene: regulation by peroxisome proliferator-activated receptor $\gamma$. Mol Cell Biol 1996;16:3410-3419
21. Gray SL, Dalla Nora E, Backlund EC et al. Decreased brown adipocyte recruitment and thermogenic capacity in mice with impaired peroxisome proliferator-activated receptor (P465L PPARy) function. Endocrinology 2006;147:5708-5714.

22. Kiecolt-Glaser JK, Preacher KJ, MacCallum RC et al. Chronic stress and age-related increases in the proinflammatory cytokine IL-6. Proc Natl Acad Sci USA 2003;100:9090-9095.

23. Ranjit N, Diez-Roux AV, Shea S et al. Socioeconomic position, race/ethnicity, and inflammation in the multi-ethnic study of atherosclerosis. Circulation 2007;116:2383-2390.

24. Miller G, Chen E, Cole SW. Health psychology: developing biologically plausible models linking the social world and physical health. Annu Rev Psychol 2009;60:501-524.

25. Rocha VZ, Libby P. The multiple facets of the fat tissue. Thyroid 2008:18:175-183

26. Rocha VZ, Libby P. Obesity, inflammation, and atherosclerosis. Nat Rev Cardiol 2009:6:399-409.

27. Takagi K, Okabe S. The effects of drugs on the production and recovery processes of the stress ulcer. Jpn J Pharmacol 1968:18:9-18.

28. Lawton JR. An investigation of the fixation and staining of lipids by a combination of malachite green or other triphenylmethane dyes with glutaraldehyde. J Microsc 1989;154:83-92.

29. Blanchette-Mackie EJ, Scow RO. Lipolysis and lamellar structures in white adipose tissue of young rats: lipid movement in membranes. J Ultrastruct Res 1981;77:295-318.

30. Anholt RR, Pedersen PL, De Souza EB, Snyder SH. The peripheral-type benzodiazepine receptor. Localization to the mitochondrial outer membrane. J Biol Chem 1986;261:576-583.

31. Bradford MM. A rapid and sensitive method for the quantitation of microgram quantities of protein utilizing the principle of protein-dye binding. Anal Biochem 1976:72:248-254.

32. WHO: Obesity in Europe Available from: <http://www.who.int/ dietphysicalactivity/publications/facts/obesity/en/>.

33. Kersten S, Desvergne B, Wahli W. Roles of PPARs in health and disease. Nature 2000;405:421-424.

34. Leibovitz E, Schiffrin EL. PPAR activation: a new target for the treatment of hypertension. J Cardiovasc Pharmacol 2007;50:120-125.

35. Kota BP, Huang TH, Roufogalis BD. An overview on biological mechanisms of PPARs. Pharmacol Res 2005;51:85-94.

36. Gealekman $\mathrm{O}$, Burkart $\mathrm{A}$, Chouinard $\mathrm{M}$ et al. Enhanced angiogenesis in obesity and in response to PPAR $\gamma$ activators through adipocyte VEGF and ANGPTL4 production. Am J Physiol Endocrinol Metab 2008;295:E1056-E1064.

37. Gazouli M, Yao ZX, Boujrad N et al. Effect of peroxisome proliferators on Leydig cell peripheral-type benzodiazepine receptor gene expression, hormone-stimulated cholesterol transport, and steroidogenesis: role of the peroxisome proliferator-activator receptor $\alpha$. Endocrinology 2002;143: $2571-2583$ 